\title{
Pengembangan Model Pembelajaran Akuntansi dengan pendekatan Kontekstual
}

\author{
Eni Susilowati ${ }^{(1)}$ \\ ${ }^{1}$ Universitas Nahdlatul Ulama Blitar \\ Email: enisusilowati1818@gmail.com
}

\begin{abstract}
Abstrak: Penelitian kontekstual yang sudah banyak dilakukan selama ini fokusnya lebih pada meningkatkan hasil belajar siswa dalam jangka pendek bukan bagaimana cara mengkontekstualkan mata pelajaran akuntansi agar bisa menjadikan pembelajaran yang penuh makna. Alasan yang mendasar peneliti menggunakan pembelajaran akutansi kontekstual adalah agar siswa dapat mengapresiasikan pengalamannya kedalam pembelajaran akuntansi dan memberikan makna didalam pembelajaranTujuan dari penelitian dan pengembangan ini adalah untuk menghasilkan produk berupa model pembelajaran akuntansi kontekstual yang dikemas dalam buku pedoman guru dan siswa, model ini ditujukan untuk siswa

Tersedia Online di

http://journal.unublitar.ac.id/pendidi

kan/index.php/Riset_Konseptual

Sejarah Artikel

Diterima pada : 10-10-2020

Disetuji pada : 31-10-2020

Dipublikasikan pada : 31-10-2020

Kata Kunci: Akuntansi, Contextual, Design based research

DOI:

http://doi.org/10.28926/riset_konseptual.v4i 4.302

kelas X. Penelitian ini menggunakan pendekatan design based research (DBR). Teknik analisis data yang digunakan adalah deskriptif kuantitatif dan kualitatif. Berdasarkan hasil penelitian dan pengembangan, hasil tanggapan siswa pada saat uji coba di SMAN 1 Kandat Kabupaten Kediri sebesar 90,5\%. Artinya Model Pembelajaran Akuntansi dengan pendekatan kontekstual dapat memahami siswa tentang konsep akuntansi yang sesuai dengan pembelajaran, khususnya dapat menjadikan pembelajaran yang bermakna yang diperuntukkan bagi siswa.
\end{abstract}

\section{PENDAHULUAN}

Orientasi Kurikulum 2013 adalah terjadinya peningkatan dan keseimbangan antara kompetensi sikap (attitude), keterampilan (skill) dan pengetahuan (knowledge). Sejumlah hal yang menjadi alasan pengembangan Kurikulum 2013 adalah (a) Perubahan proses pembelajaran (dari siswa diberi tahu menjadi mencari tahu) dan proses penilaian (dari berbasis output menjadi berbasis proses dan output). Implementasi kurikulum 2013 dalam pembelajaran menerapkan pendekatan saintifik dan penilaian otentik untuk mengukur semua kompetensi siswa, dengan menggunakan instrument utama penilaian adalah portofolio yang dibuat oleh peserta didik, sehingga dituntut adanya keseimbangan antara proses dan hasil. Hal ini akan diaplikasikan pada setiap jenjang pendidikan, SMP, SMA dan SMK.

Siswa sekolah menengah pertama dan sekolah menengah atas serta Sekolah menengah kejuruan yang masih berada pada taraf operasional konkrit yaitu pemahaman pada suatu yang nyata atau tidak abstrak, maka siswa perlu pengalaman belajar langsung dan nyata dalam kehidupan sehari-hari. Perkembangan siswa secara holistik, berlangsung secara terpadu (aspek dimensi satu mempengaruhi aspek dimensi yang lain). Maka salah satu alternative pembelajaran yang sesuai untuk diterapkan di SMA dan SMK adalah pembelajaran kontekstual atau Contextual Teaching and Learning.

Alasan yang mendasar peneliti menggunakan pembelajaran akuntansi kontekstual adalah agar siswa dapat mengapresiasikan pengalamannya kedalam pembelajaran akuntansi dan memberikan makna didalam pembelajaran. Hasil dari observasi dan wawancara menunjukkan bahwa pembelajaran akuntansi di SMAN 1 
Kandat hanya mendengarkan ceramah dari guru sehingga siswa pasif dan hanya terfokus pada penjelasan dari guru saja. Pembelajaran masih belum memenuhi tujuh komponen Contextual Teaching and Learning terlihat saat proses pembelajaran guru hanya memberikan contoh transaksi akuntansi yang terjadi dikehidupan sehari-hari siswa. Masalah dalam pengembangan ini adalah dibutuhkannya Pengembangan Model Pembelajaran Akuntansi dengan pendekatan Kontekstual yang menjadi karakteristik siswa SMAN 1 kandat.

\section{METODE}

Pengembangan penelitian ini menggunakan pendekatan Design Based Research (DBR) terdapat ciri khusus yaitu suatu model penelitian pengembangan produk yang dibutuhkan, melibatkan dan berkolaborasi dengan praktisi. Penerapan penelitian ini menggunakan metode yang digunakan sistematis namun flesibel untuk peningkatan praktik pendidikan berdasarkan kolaborasi peneliti dan praktisi tanpa adanya rekayasa. Langkah pengembangan dalam penyusunan draft Sintaks dan skenario pembelajaran dan uji kelayakan prototipe melibatkan kolaborasi tim. Selanjutnya ini adalah alur prosedur penelitian dan pengembangan, (a) fase pertama: identifikasi masalah, (b) fase kedua: merumuskan produk pengembangan, (c) fase ketiga: desain dan pengembangan produk, (d) fase keempat: uji coba produk pembelajaran, (e) fase kelima: evaluasi hasil uji coba produk pembelajaran, (f) fase keenam: mengkomunikasikan uji coba produk diantaranya: (a) desain uji coba: uji coba ahli pendidikan dan ahli meteri, uji coba praktisi, uji coba lapangan, (b) subjek instrumen pengumpulan data dalam penelitian dan pengembangan ini diantaranya: survei dengan angket, wawancara, dokumentasi proses pembelajaran ekonomi dilakukan oleh peneliti oleh Guru Akuntansi di SMAN 1 Kandat yang dilakukan peneliti pada saat mengujicobakan produk pengembangan, kuisioner yang diberikan kepada subjek uji coba pada tahap evaluasi untuk mengetahui kelayakan dan keberterimaan produk yang telah dikembangkan.

\section{HASIL dan PEMBAHASAN}

A.Paparan Pelaksanaan

1.Identifikasi dan Analisis Situasi

Kegiatan pertama kali yang dilakukan oleh peneliti dilapangan adalah meminta ijin kepada kepala sekolah SMAN 1 KANDAT. Permohonan ijin penelitian awal dilakukan melalui surat permohonan penelitian yang diberikan langsung kepada kepala sekolah SMAN 1 KANDAT. Lalu melakukan wawancara dengan guru akuntansi. Memberikan angket untuk guru dan siswa sebagai survey awal pertama.

2.Eksplorasi Lanjut

Eksplorsi lanjut dilakukan setelah komunikasi awal kepada guru dalam hal ini sebagi praktisi dan siswa pada tahap eksplorasi awal. Informasi yang didapat pada eksplorasi lanjut adalah mencakup kondisi aktivitas pembelajaran yang terangkum didalam identifikasi masalah dalam proses pembelajaran secara rinci.

B.Paparan pengembangan

1.Identifikasi masalah dan asesmen kebutuhan terhadap model pembelajaran akuntansi dengan pendekatan kontekstual

Tahap identifikasi masalah dan assessment kebutuhan terhadap model pembelajaran ekonomi kontekstual sebagai proses menganalisis kebutuhan guru dan siswa. Melalui observasi awal yang dilakukan di SMAN 1 KANDAT dari bulan agustus sampai september. Observasi ini dilakukan untuk mengetahui kondisi RPP guru akuntansi, karakteristik siswa, lingkungan siswa, dan masalah-masalah siswa dalam pembelajaran. Berdasarkan analisis kebutuhan guru dan siswa, belum pernah ada penelitian sebelumnya yang mengembangkan model pembelajaran akuntansi dengan pendekatan kontekstual.

Hasil wawancara dengan guru ekonomi kelas XI IPS yang menyatakan bahwa RPP guru sudah sesuai dengan kurikulum 2013 tetapi guru belum faham makna 
kompetensi inti yang harus masuk dalam proses pembelajaran dan dalam kegiatan pembelajarannnya masih belum mencerminkan pembelajaran kontekstual. Guru menganggap RPP bukan hal yang begitu penting dalam proses pembelajaran, yang terpenting siswa mampu memahami materi yang disampaikan guru. Kebanyakan guru hanya membuat RPP saat akan ada pemeriksaan atau saat akan pendampingan kurikulum 2013 saja. Pengukuran hasil belajar siswa hanya dengan menggunakan tes tulis yang mencakup ranah koknitif saja. Seharusnya guru juga melatih siswa mampu membuat apa didalam pembelajaran, contohnya membuat cerita pengalaman siswa, karya ilmiah atau peta konsep. Sehingga siswa mendapatkan pembelajaran yang penuh makna serta mengaitkan materi dengn kehidupan sehari-hari mereka.

Peneliti juga mengamati proses pembelajaran ekonomi yang tejadi dikelas. Masih banyak terdapat siswa yang semaunya sendiri, duduk dibawah dan mengobrol dengan temannya. Pembelajaran pun kurang kondusif karena guru belum mampu mengelola kelas dengn baik. Disamping itu guru juga kurang tegas dalam menegur siswa yang tidak mengikutipembelajaran dengan fokus. Siswa juga menjawab pertanyaan dari guru dengan bergurau yang mengurutkan semua jawaban mulai dari pilihan A - E.

2.Perumusan produk pengembangan dengan berkolaborasi bersama praktisi, tim ahli dan peserta didik.

Perumusan model pembelajaran akuntansi kontekstual dilakukan kolaborasi dengann tim ahli,peserta didik,peneliti,dan praktisi. Hasil kolaborasi selanjutnya diidentifikasi untuk pengembangan model pembelajaran akuntansi kontekstual yang sesuai dengan standar isi permendiknas dan kebutuhan siswa.

Berdasarkan hasil kolaborasi peneliti dengan peserta didik, praktisi, dan tim ahli serta hasil observasi terhadap Permendikbud No.65 Tahun 2013 tentang standar proses dan observasi terhadap pengamatan proses pembelajaran ekonomi di kelas, selanjutnya peneliti merumuskan desain konseptual skenario pembelajaran yang meliputi; (a) Pemetaan Nilai-nilai ekonomi kontekstual; (b) Pengidentifikasian dan pemetaan materi-materi yang memiliki substansi dekat dengan ekonomi kontekstual mata pelajaran akuntansi; (c) Merumuskan sintaks model pembelajaran akuntansi kontekstual.

3.Penyusunan desain dan pengembangan model pembelajaran akuntansi kontekstual

Pengembangan model pembelajaran akuntansi kontekstual yang telah disusun sintaks dan penjabarannya, kemudian tahap selanjutnya yaitu peneliti merancang skenario pembelajaran ekonomi untuk materi kebutuhan akuntansi dengan menggunakan pendekatan konstruktivistik dengan model pembelajaran akuntansi kontekstual. Alasan pemilihan materi kebutuhan ekonomi didasarkan pada hasil pemetaan SK dan KD mata pelajaran akuntansi kelas XI IPS dan hasil angket kebutuhan guru yang menyatakan bahwa materi kebutuhan ekonomi dirasa sangat penting untuk mengilustrasikan keadaan nyata dilingkungan tempat tinggal siswa.

Penyusunan desain dan pengembangan model pembelajaran ekonomi berkarakter pancasila ini terdiri dari 3 (tiga) tahap, diantaranya: (a) penyusunan prototype skenario pembelajaran yang didasarkan pada desain konseptual yang berupa model pembelajaran akuntansi berkarakter pancasila, (b) validasi oleh praktisi (guru mata pelajaran akuntansi) 3) draf prototype siap untuk diujicobakan di lapangan 4. Uji Coba Prototype Skenario Pembelajaran Akuntansi

Uji coba prototype skenario pembelajaran ekonomi dilaksanakan sebanyak dua kali di SMAN 1 KANDAT. Penelitian ini bertujuan menjadikan pembelajaran akuntansi kontekstual yang tidak hanya mengajarkan teoritis dan berkhayal mengenai laporan keuangan saja tetapi juga menjadikan sebuah pembelajaran yang penuh makna.

Evaluasi Kelayakan Prototype Model pembelajaran akuntansi kontekstual. Mengetahui layak tidaknya prototype peneliti meminta tanggapan dari peserta didik tentang model pembelajaran akuntansi kontekstual yang telah diterapkan dalam proses pembelajaran dalam membahas materi akuntansi perusahaan jasa. Berdasarkan hasil analisis terhadap tanggapan peserta didik SMAN 1 KANDAT, hasil 
kelayakan sebesar 90,5\% mengenai tanggapan siswa berupa data kualitatif dari respon yang diberikan maka dapat dikatakan bahwa model pembelajaran akuntansi kontekstual diimplementasikan dalam pembelajaran akutansi pada materi akuntansi perusahaan jasa. Tanggapan secara kualitatif menyatakan bahwa model pembelajaran akuntansi kontekstual dapat memahamkan peserta didik tentang akutansi perusahaan jasa yang mampu mangaitkan antara materi dengan kehidupan siswa sehari-hari.

5. Penyempurnaan Prototipe dan Mengkomunikasikan

Penelitian dan pengembangan ini menghasilkan produk diantaranya: (a) model pembelajaran akuntansi kontekstual yang direncanakan dalam bentuk sintak, desain pembelajaran dan scenario pembelajaran, (b) buku panduan guru dan siswa. Selama penelitian menemukan beberapa temuan diantaranya adalah sebagai berikut :

A. Ketidaksesuaian antara Rencana Pelaksanaan Pembelajaran dengan pelaksanaan pembelajaran yang diterjadikan dikelas selama bejalannya proses pembelajaran, materi yang diajarkan terfokus pada LKS dan buku paket. Belum tercermin pembelajaran akuntansi yang kontekstual.

B. Pembelajaran akuntansi tidak mengaitkan materi antara kehidupan siswa. Sehingga ketika peneliti dalam proses pembelajaran menggunakan model pembelajaran akuntansi kontekstual mendapat respon yang baik, karena siswa akan lebih antusias didalam belajar . Pembelajaran yang berkaitan dengan kehidupan sehari-hari siswa bisa menceritakan pengalaman mereka kedalam pembelajaran.

C. Pembelajan akuntansi yang terpaku pada teoritis saja, tidak memberikan kesempatan siswa untuk mengamati peristiwa-peristiwa atau transaksitransaksi secara langsung dan bagaimana pemecahan dalam peristiwaperistiwa tersebut.

D. Peneliti juga mengajak siswa untuk membuat siklus akuntansi

E. Siswa merasa antusias ketika diberikan pembelajaran dengan menggunakan model pembelajaran akuntansi kontekstual, karena siswa dalam belajar merasa dekat dengan apa yang dipelajari.

F. Hasil pembelajaran

Kajian dalam refleksi melalui desain pembelajaran diantaranya: pemahaman siswa terhadap definisi makna akuntansi perusahaan jasa Implementasi terhadap pemahaman makna akuntansi perusahaan jasa (c) bentuk simulasi kegiatan pembelajaran akuntansi kontekstual. Kegiatan pembelajaran terdiri dari eksplorasi awal, lanjut dan tindakan dapat dilihat dari siswa individu maupun kelompok. Siswa memperoleh wawasan baru untuk membuat perusahaan jasa, tahap pre-elimanary survey sebelum kegiatan pembelajaran siswa hanya memahami akuntansi perusahaan jasa. Namun setelah kegiatan pembelajaran berlangsung siswa memahami makna akuntansi perusahaan jawa, tidak hanya jurnal umum saja tapi buku bersar dan neraca dan bagaimana cara mereka mampu mengaitkan antara materi dengan kehidupan sehari-hari. Kegiatan pembelajaran terjadi perubahan wawasan siswa melalui kemampuan berfikir kritis, analitis dalam penerapan pemahaman tersebut kedalam penyelesaian suatu kasus simulasi kegiatan pembelajaran. 


\section{Merumuskan Sintaks Model Pembelajaran Akuntansi Kontekstual}

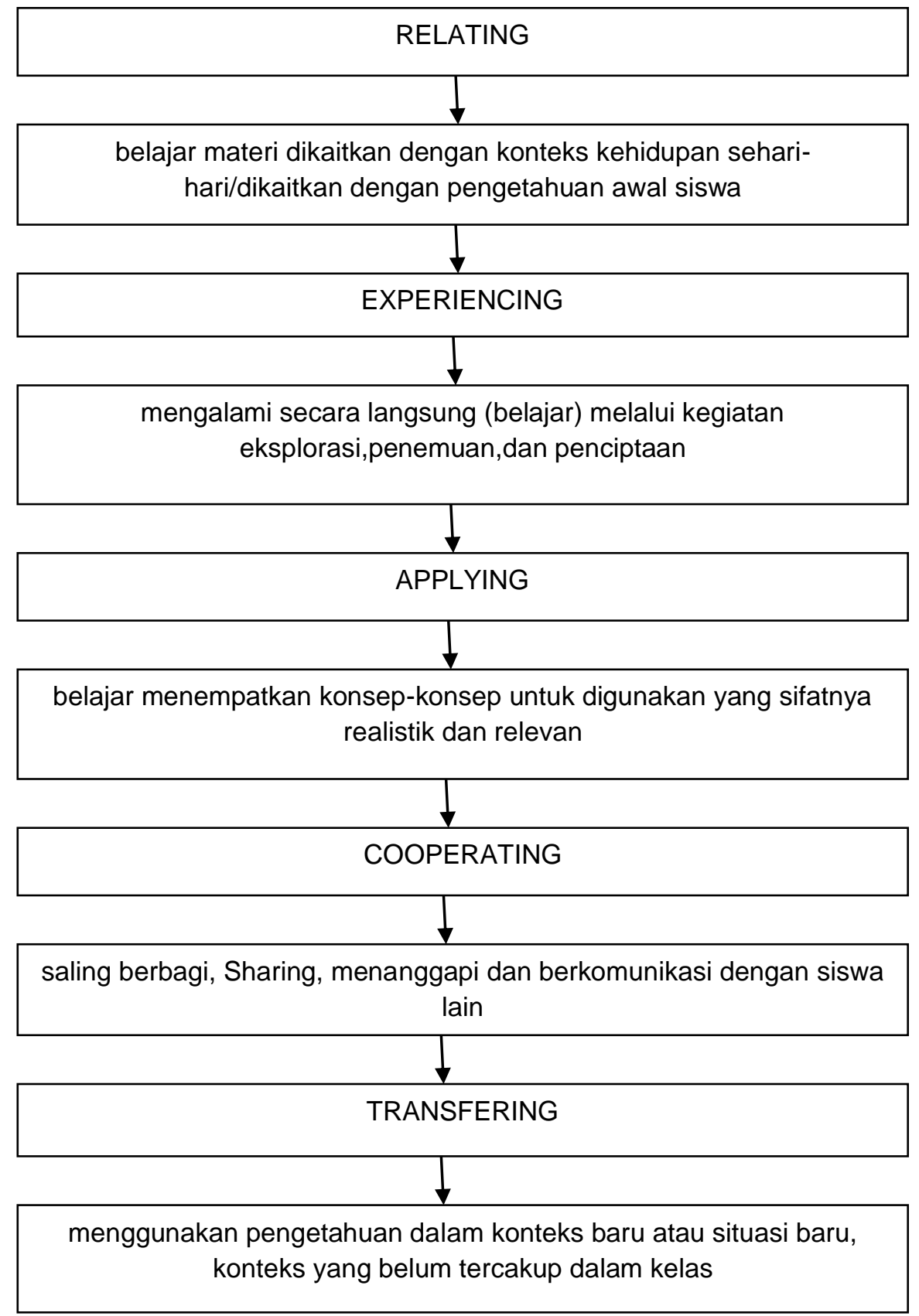




\section{Kajian Produk}

Selama proses pengembangan selama ini maka produk yang dihasilkan adalah sebuah produk pengembangan model pembelajaran akuntansi kontekstual. Pengembangan model pembelajaran ini dilakukan dengan sistematis dan berurutan sesuai kebutuhan siswa. Berikut kajian terhadap produk pengembangan, diantaranya:

1. Pengembangan model pembelajaran akuntansi kontekstual dilakukan dengan (empat) fase khusus dari Design Based Research (DBR).

2. Komponen skenario pembelajaran dengan model pembelajaran akuntansi kontekstual sesuai dengan harapan siswa dan tujuan didalam kurikulum 2013.

3. Komponen skenario pembelajaran dengan model pembelajaran akuntansi kontekstual diperuntukkan untuk materi ekonomi pasar dalam perekonomian SMAN 1 KANDAT kelas XI IPS.

\section{KESIMPULAN}

Pembelajaran dapat dikatakan ideal salah satunya adalah dengan mengkontekstualkan materi/teori yang dipelajari disekolah kedalam kehidupan seharihari. Kebutuhan pelajaran akuntansi disini siswa mampu merealisasikan pembelajaran kontekstual dengan Design Based Research (DBR) melalui pendekatan REACT.

\section{DAFTAR RUJUKAN}

Akcay, B. (2009). Problem Based Learning in Science Education. Journal of Turkish Science education. 6 (1): 26-36.

Anita Lie. (2007). Kooperatif Learning (Mempraktikkan Cooperative Learning di Ruang-ruang Kelas). Jakarta: PT. Grasindo.

Bern, R., \& Ericson, P. (2001). Contextual teaching and learning : Preparing Students For The New Economy. Highlight zone : research @ work. Columbus, ohio:ohio State University, national dissemination center for career and technical education. (issue no.5).

Dewey, J. (1916). Democracy and education : An introduction to the philosophy of education. New York : The Macmillan Company.

Dimiyanti \& Mudjiono. (2009). Belajar dan Pembelajaran. Jakarta: PT. Rineka Cipta.

Elaine. B. Johnson. (2002). Contextual Teaching and Learning: Menjadikan Kegiatan belajar mengajar Mengasikkan dan Bermakna. Bandung. MLC

Gronlund N.E \& Linn R. (1990). Mesurement and Evaluation Teaching. New York: Macmillan Publishing Company.

Hamalik, O. (2008). Proses belajar mengajar. Jakarta: PT. Bumi Aksara.

CORD. (1999). Center for Occupational Research and Development, Inc. United States of America.

Isjoni. (2009). Cooperatif Learning. Bandung : Alfabeta.

Kesuma, S. (2003). Psikologi Pendidikan. Jakarta: PT. Grasindo Persada.

Kunandar. (2007). Guru Profesional. Jakarta: Raja PT. Grafindo Persada.

Nurhadi. (2002). Pendekatan Kontekstual. Jakarta : Depdiknas.

Pendekatan Pembelajaran Kontekstual (CTL) di Fakultas Sastra Universitas Negeri Malang. Surakarta: Panitia Sertifikasi Guru Rayon 13 Surakarta.

Peraturan Menteri Pendidikan Dan Kebudayaan Nomor 65 Tahun 2013 Tentang Standar Proses Pendidikan Dasar Dan Menengah. Sofyan, Gusarmin dan Amiruddin B. (2007). Modul Diklat Profesi Guru Model-Model Pembelajaran I. Kendari: Universitas Haluoleo.

Sugiyanto. (2010). Model-model Pembelajaran Inovatif. Surakarta : Yuma Pustaka.

Uno, B. Hamzah. 2005. Orientasi Baru dalam Psikologi Pembelajaran. Jakarta: PT. Bumi Aksara. 
Wanti, R. (2003). Pembelajaran Sistem Persamaan Linear Untuk Pemecahan Masalah Berbasis CTL Di Kelas I SMU Negeri 5 Malang. Tesis. Malang: Universitas Negeri Malang.

Wina, S. (2006). Strategi Pembelajaran. Jakarta: Kencana Prenada Media Grup. 